\title{
Somatostatin receptor scintigraphy in the initial staging of Hodgkin's disease
}

\author{
P. J. van den Anker-Lugtenburg, ${ }^{1,4}$ E. P. Krenning, ${ }^{2,3}$ H. Y. Oel, ${ }^{2}$ M. P. Van Hagen, ${ }^{3}$ C. J. H. Gerrits, ${ }^{1}$ \\ J. C. Reubi, ${ }^{5}$ S. W. J. Lamberts ${ }^{3}$ and B. Löwenberg ${ }^{1,4}$ Departments of ${ }^{1}$ Haematology, ${ }^{2}$ Nuclear M edicine \\ and ${ }^{3}$ Internal M edicine III, Erasmus U niversity and University Hospital Rotterdam, The N etherlands, \\ ${ }^{4}$ Department of Haematology, Daniel den Hoed Cancer Centre, Rotterdam, The Netherlands, and \\ ${ }^{5}$ Institute of Pathology, University of Berne, Switzerland
}

Received 15 August 1995; accepted for publication 5 December 1995

\begin{abstract}
Summary Somatostatin receptor (SS-R) scintigraphy has been successfully used in the visualization of a variety of neuroendocrine tumours. In vitro studies have shown that SS-Rs are present in human malignant lymphomas. We conducted a prospective study in 56 consecutive untreated patients with histologically proven Hodgkin's disease (HD) and compared the results of SS-R scintigraphy with physical and radiological examinations as initial evaluation.

SS-R scintigraphy was positive in 55/56 (98\%) patients at sites of documented disease. In 20 patients SS-R scintigraphy disclosed lymphoma localizations not revealed following procedures of conventional staging. As a result in 12 patients (21\%) SS-R scintigraphy produced a change of stage and in
\end{abstract}

seven patients $(13 \%)$ the additional information obtained from SS-R scintigraphy led to a change of treatment. SS-R scintigraphy failed to visualize sites of HD in four patients, mainly in the abdominal area. In three patients a falsepositive result was obtained.

These data show that SS-R scintigraphy provides an imaging technique that appears to visualize tumours in most patients with $\mathrm{HD}$ and may be clinically useful in the management of these patients.

Keywords: somatostatin, somatostatin receptor scintigraphy, Hodgkin's disease, octreotide, staging of Hodgkin's disease.
Precise staging of the dissemination of the disease is critical in the treatment and prognosis of patients with Hodgkin's disease (HD). To determine the extent of the disease, several imaging techniques are currently employed, e.g. plain chest radiography, computed tomography (CT), sonography and lymphangiography (North \& Jing, 1988). These techniques are also used to assess the response of the disease at different sites to treatment. Gallium scintigraphy is variably used in the work-up of patients with HD (Front et al, 1995).

A variety of human neoplasms express somatostatin receptors (SS-Rs). SS-Rs have been found in neuroendocrine (Reubi et al, 1987, 1990a, c), breast (Reubi et al, 1990b; van Eijck et al, 1994) and brain tumours (Reubi et al, 1986). In order to take advantage of SS-R tissue expression, radiolabelled somatostatin (SS) analogues have been applied to visualize SS-R-positive tumours in vivo with a gammacamera. SS-R scintigraphy has proved clinically useful for refined tumour localization in patients with carcinoid

Correspondence: Dr P. J. van den Anker-Lugtenburg, Department of Haematology, University Hospital Rotterdam, Dr Molewaterplein 40, 3015 GD Rotterdam, The Netherlands. tumours, pancreatic endocrine tumours and paragangliomas (Krenning et al, 1989, 1995; Lamberts et al, 1990; Kwekkeboom et al, 1993).

SS-Rs are expressed on the membranes of human lymphoid cells, including malignant lymphoma and HD (Reubi et al, 1992), as has become apparent from autoradiography of tissue sections. There is as yet only limited experience with SS-R scintigraphy in patients with HD (Bares et al, 1993; van Hagen et al, 1993; Bong et al, 1994; Lipp et al, 1995). We set out to evaluate SS-R scintigraphy as a potentially useful method for in vivo imaging of tumour deposits in patients with HD. Here we present the results of a prospective study in 56 newly diagnosed, previously untreated, patients with histologically proven HD.

\section{PATIENTS AND METHODS}

Patients. 56 consecutive, newly diagnosed and previously untreated patients with histologically proven HD were enrolled in the study. The stage of the disease according to the Ann Arbor classification (Carbone et al, 1971) was 
established by conventional methods which included a physical examination, chest radiography, CT of chest, abdomen and pelvis, bone marrow biopsy, and occasionally lymphangiography. All patients had given informed consent to the study, which was approved by the ethics committee of the University Hospital Rotterdam.

Scintigraphy. SS-R scintigraphy was performed after intravenous injection of the radioactive labelled SS analogue $\left[{ }^{111}\right.$ In-DTPA-D-Phe ${ }^{1}$ octreotide (obtained from Mallinckrodt Medical BV, Petten, The Netherlands). The preparation of $\left[{ }^{111}\right.$ In-DTPA-D-Phe $\left.{ }^{1}\right]$ octreotide, the dose administered (222 MBq) and the technique of scintigraphy with the gamma-camera, as well as with single photon emission computed tomography (SPECT) have recently been described (Bakker et al, 1991; Krenning et al, 1992, 1993, 1994, 1995). Planar total body scintigraphy was performed $24 \mathrm{~h}$ post-injection with a largefield-view gamma camera (Counterbalance 3700 and ROTA II; Siemens Gammasonics, Erlangen, Germany) equipped with a medium-energy collimator. In all patients SPECT images of the upper abdomen were made. For both planar and SPECT scintigraphy, images with a long exposure time were obtained, e.g. $15 \mathrm{~min}$ for planar views. Repeat scintigraphy of the abdomen was performed $48 \mathrm{~h}$ post-injection when $24 \mathrm{~h}$ scintigraphy showed accumulation in the abdomen. In normal individuals a physiological accumulation of radioactivity may be seen at $24 \mathrm{~h}$ after intravenous administration of $\left[{ }^{111} \ln\right.$-DTPA-D-Phe ${ }^{1}$ ]octreotide in the pituitary and thyroid gland, the liver, spleen, kidneys, the urinary bladder and occasionally in the gall-bladder. The presence of intestinal radioactivity (mainly in the colon at $24 \mathrm{~h}$ ) is due to some hepatobiliary clearance of $\left[{ }^{111} \mathrm{In}-\mathrm{DTPA}-\mathrm{D}-\mathrm{Ph} \mathrm{e}^{1}\right]$ octreotide
Table I. Clinical features and SS-R scintigraphy results of 56 patients with HD.

\begin{tabular}{lc}
\hline Age (yr) & \\
Median & $33 \cdot 1$ \\
Range & $15-66$ \\
Sex & \\
$\quad$ Female & $29(52 \%)$ \\
Male & $27(48 \%)$ \\
Histologic subtype & \\
Lymphocyte predominance & $4(7 \%)$ \\
Nodular sclerosis & $46(82 \%)$ \\
Mixed cellularity & $6(11 \%)$ \\
Clinical stage* & \\
Stage I & $11(19 \%)$ \\
Stage II & $29(52 \%)$ \\
Stage III & $7(13 \%)$ \\
Stage IV & $9(16 \%)$ \\
SS-R scintigraphy results & \\
Positive & $55(98 \%)$ \\
Negative & $1(2 \%)$ \\
\end{tabular}

*Based on physical examination and conventional staging methods.

and may be reduced following the use of laxatives (Krenning et al, 1992, 1993). The SS-R scans were evaluated by two investigators at the same time without knowing patient identity or results of the conventional diagnostic work-up. Finally, the results of the SS-R scans and conventional
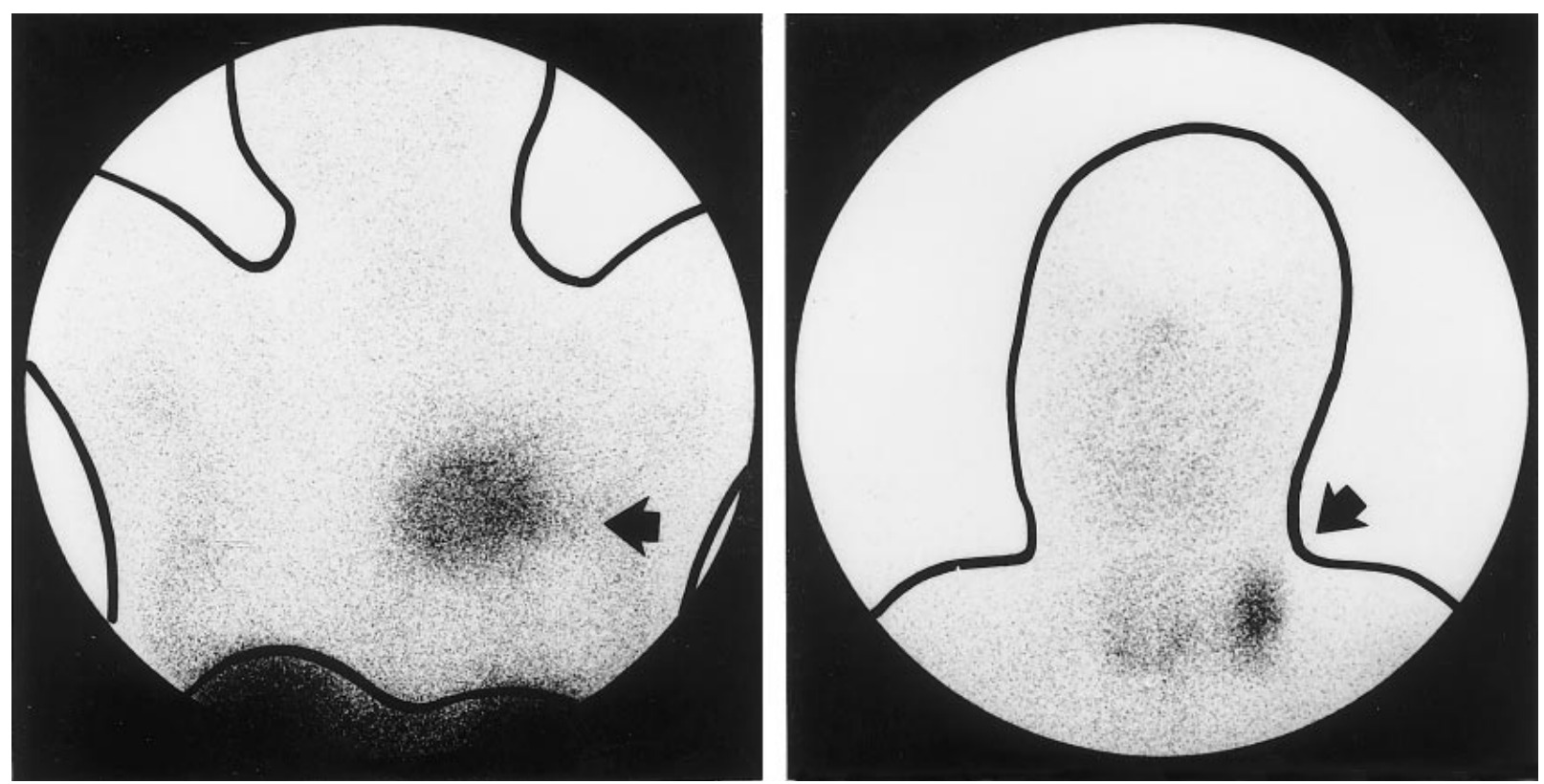

Fig 1. (A) Visualization of mediastinal lymph nodes (arrow) in a patient with stage IB HD, mixed cellularity, by SS-R scintigraphy at $24 \mathrm{~h}$ (anterior image of the thorax). On CT a large mediastinal mass of $11 \times 9 \mathrm{~cm}$ was shown. In this patient normal accumulation of radioactivity in the thyroid, not seen on this image, was apparent on the anterior image of the head and neck. (B) SS-R scintigraphy reveals positive supraclavicular lymph nodes in the neck (arrow) at $24 \mathrm{~h}$ in a patient with stage IA HD, mixed cellularity (anterior image of the head and neck). Normal accumulation of radioactivity is seen in the pituitary and thyroid. On physical examination a lymph node of $3 \mathrm{~cm}$ diameter was palpated. 
diagnostic tests were compared by the study coordinator. In case of discrepancies additional radiodiagn ostic investigations were scheduled before the beginning of treatment and, if practically possible, cytological or histological verification was sought. In nine patients SS-R scintigraphy was repeated after therapy. All patients were followed during and after treatment.

Autoradiography. In three patients SS-R autoradiography was performed on $10 \mu \mathrm{m}$ thick cryostat sections of tumour samples, using a iodinated SS octapeptide analogue $\left[{ }^{125} \mathrm{I}\right.$ Tyr $^{3}$ ]octreotide ( $\left.{ }^{125} \mathrm{I}-204-090\right)$ as radioligand (Reubi et al, 1987, 1990a).

\section{RESULTS}

The clinical characteristics of the 56 patients with HD in whom SS-R scintigraphy was performed are given in Table I.
SS-R scintigraphy indicated SS-R positivity at areas of documented active disease in 55 cases (98\%). Two examples of SS-R scintigraphy of lymphoma localizations above the diaphragm are shown in Fig $1 \mathrm{~A}$ (mediastinum) and Fig $1 \mathrm{~B}$ (neck). In Figs 2A - C a SS-R scintigram of multiplepara-aortic abdominal lymph nodes is shown.

Additional sites of HD revealed by SS-R scintigraphy (20 patients) In 20 patients SS-R scintigraphy disclosed activity suggestive of lymphoma which had not been revealed following physical and radiological examination. Table II lists the additional sites of disease as suggested by SS-R scintigraphy in comparison with the results of conventional staging in these 20 patients. 27 additional SS-R positive sites of disease became apparent in these 20 patients. Most new localizations were above the diaphragm, i.e. in the neck ( $n=12$ cases), mediastinum $(n=3)$, axilla $(n=3)$, infraclavicular area $(n=1)$ and lung
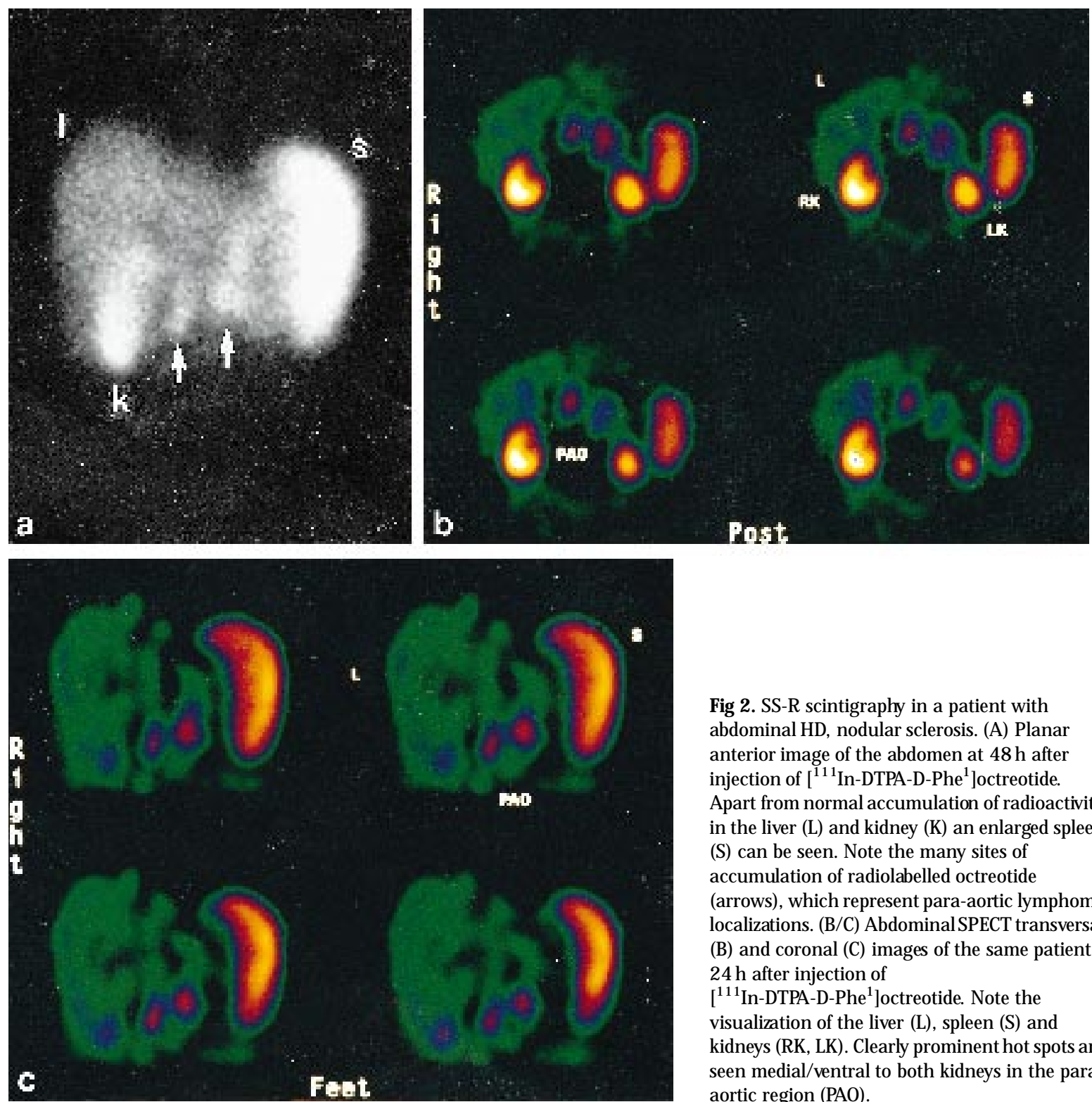

Fig 2. SS-R scintigraphy in a patient with abdominal HD, nodular sclerosis. (A) Planar anterior image of the abdomen at $48 \mathrm{~h}$ after injection of [ ${ }^{111}$ In-DTPA-D-Phe $\left.{ }^{1}\right]$ octreotide. A part from normal accumulation of radioactivity in the liver $(\mathrm{L})$ and kidney $(\mathrm{K})$ an enlarged spleen (S) can be seen. Note the many sites of accumulation of radiolabelled octreotide (arrows), which represent para-aortic lymphoma localizations. (B/C) A bdominal SPECT transversal (B) and coronal (C) images of the same patient, $24 \mathrm{~h}$ after injection of

$\left[{ }^{111}\right.$ In-DTPA-D-Phe $\left.{ }^{1}\right]$ octreotide. Note the visualization of the liver (L), spleen (S) and kidneys (RK, LK). Clearly prominent hot spots are seen medial/ventral to both kidneys in the paraaortic region (PAO). 
Table II. Additional sites of disease demonstrated following SS-R scintigraphy in 20/56 patients with HD: a comparison between SS-R scintigraphy and conventional staging methods.

\begin{tabular}{|c|c|c|c|c|}
\hline Pt & Additional sites of disease & Verification $(+=\mathrm{HD})$ & $\begin{array}{l}\text { Repeated SS-R } \\
\text { scintigraphy }\end{array}$ & $\begin{array}{l}\text { Change } \\
\text { clinical } \\
\text { stage }\end{array}$ \\
\hline 2 & Neck, para-aortic & $+\mathrm{CT}$, follow-up & n.d. & $\mathrm{II} \rightarrow \mathrm{III}$ \\
\hline 4 & Neck & n.d. & n.d. & No \\
\hline 5 & Neck & + cytology, follow-up & n.d. & No \\
\hline 6 & Neck & + physical examination, follow-up & n.d. & No \\
\hline 8 & Neck, mediastinum & $+C T$, follow-up & n.d. & $\mathrm{I} \rightarrow \mathrm{II}$ \\
\hline 10 & Neck, lung negative & + physical examination, follow-up & n.d. & $\mathrm{IV} \rightarrow \mathrm{II}$ \\
\hline 13 & Para-aortic & + & Yes & $\mathrm{II} \rightarrow \mathrm{III}$ \\
\hline 14 & Neck & n.d. & n.d. & No \\
\hline 17 & Neck & + sonography, follow-up & n.d. & No \\
\hline 20 & Mediastinum, axilla, lung & + & Yes & $\mathrm{III} \rightarrow \mathrm{IV}$ \\
\hline 25 & Para-aortic & n.d. & n.d. & $\mathrm{II} \rightarrow \mathrm{III}$ \\
\hline 27 & Infraclavicular & $+\mathrm{CT}$, follow-up & n.d. & $\mathrm{I} \rightarrow \mathrm{II}$ \\
\hline 28 & Neck, mediastinum & $+\mathrm{CT}$, follow-up & n.d. & $\mathrm{I} \rightarrow \mathrm{II}$ \\
\hline 29 & Neck & + & Yes & No \\
\hline 33 & Neck, axilla, inguinal & + physical examination, follow-up & Yes & No \\
\hline 35 & Neck & + & Yes & $\mathrm{I} \rightarrow \mathrm{II}$ \\
\hline 44 & Axilla & + physical examination, follow-up & Yes & No \\
\hline 50 & Para-aortic & $+\mathrm{CT}$, follow-up & Yes & $\mathrm{II} \rightarrow \mathrm{III}$ \\
\hline 52 & Para-aortic & + & Yes & $\mathrm{II} \rightarrow \mathrm{III}$ \\
\hline 55 & Inguinal & + histology, follow-up & Yes & $\mathrm{II} \rightarrow \mathrm{III}$ \\
\hline
\end{tabular}

$(n=1)$, but also in the para-aortic region $(n=5)$ and the inguinal area $(n=2)$. In patient 10 , following the results of SS-R scintigraphy, we confirmed the presence of an abnormal lymph node in the neck on repeated palpation $(1.5 \mathrm{~cm}$ diameter). In the same patient multiple small intrapulmonal 'lesions' were seen on $\mathrm{CT}$, which were read as possible Hodgkin localizations. The intrapulmonal lesions were negative on SS-R scintigraphy. After six cycles of chemotherapy no residual masses were seen. The radiographic intrapulmonal abnormalitiesthat had been SS-R negative had not changed and were retrospectively interpreted as preexistent abnormalities of unclear nature (follow-up time 2 years). In the majority of patients additional investigations were performed to verify the diagnosis at discrepant sites (see Table II). The superiority of SS-R scintigraphy was confirmed in $12 / 20$ patients, i.e. by repeated palpation $(n=4)$, subsequent radiodiagnostic tests $(n=6)$ and/or cytopathology $(n=2)$. In the latter 12 patients the physical and radiological abnormalities disappeared following cytotoxic treatment (Table II, follow-up). In nine patients SS-R scintigraphy was repeated after successful chemotherapy and in all patients SS-R scintigraphy had become entirely negative (Table II, repeated SS-R scintigraphy).

In 12 patients the discrepancies between SS-R scintigraphy

Table III. False-negative SS-R scintigraphy in 4/56 patients with HD: a comparison between SS-R scintigraphy and conventional staging methods.

\begin{tabular}{|c|c|c|c|c|}
\hline Pt & $\begin{array}{l}\text { Sites of disease: } \\
\text { conventional methods }\end{array}$ & $\begin{array}{l}\text { Clinical stage: } \\
\text { conventional } \\
\text { methods }\end{array}$ & $\begin{array}{l}\text { Sites of disease: } \\
\text { SS-R scintigraphy }\end{array}$ & $\begin{array}{l}\text { Clinical stage: } \\
\text { SS-R scintigraphy }\end{array}$ \\
\hline 3 & $\begin{array}{l}\text { Left neck, mediastinum, } \\
\text { lung, para-aortic }\end{array}$ & IV & $\begin{array}{l}\text { Left neck, mediastinum, } \\
\text { lung }\end{array}$ & IV \\
\hline 7 & $\begin{array}{l}\text { Left neck, mediastinum, } \\
\text { para-aortic }\end{array}$ & III & Left neck, mediastinum & II \\
\hline 26 & $\begin{array}{l}\text { Mediastinum, para-aortic, } \\
\text { spleen }\end{array}$ & III & $\begin{array}{l}\text { Left neck, mediastinum, } \\
\text { spleen }\end{array}$ & III \\
\hline 40 & $\begin{array}{l}\text { Mediastinum, para-aortic, } \\
\text { left para-iliac, left inguinal, } \\
\text { spleen }\end{array}$ & III & $\begin{array}{l}\text { Mediastinum, para-aortic, } \\
\text { left para-iliac, left inguinal }\end{array}$ & III \\
\hline
\end{tabular}


Table IV. Abdominal lymph node or spleen involvement in HD: a comparison between SS-R scintigraphy and conventional staging methods (CSM).

\begin{tabular}{llll}
\hline Sites of disease & $\begin{array}{l}\text { SS-R scinti- } \\
\text { graphy=l } \\
\text { CSM }=\end{array}$ & $\begin{array}{l}\text { SS-R scinti- } \\
\text { graphy-l } \\
\text { CSM+ }\end{array}$ & $\begin{array}{l}\text { SS-R scinti- } \\
\text { graphy+l } \\
\text { CSM- }\end{array}$ \\
\hline $\begin{array}{l}\text { Para-aortic } \\
\text { Spleen }\end{array}$ & 5 & 3 & 5 \\
Total & 7 & 1 & - \\
& 12 & 4 & 5 \\
\hline
\end{tabular}

SS-R scintigraphy, somatostatin receptor scintigraphy; CSM, conventional staging methods. SS-R scintigraphy $=/ \mathrm{CSM}=$ : abnormalities visualized by SS-R scintigraphy and CSM; SS-R scintigraphy-/ CSM+: abnormalities visualized only by CSM; SS-R scintigraphy + / CSM - : abnormalities visualized only by SS-R scintigraphy. Numbers indicate patients with para-aortic or spleen abnormalities that were evident on SS-R scintigraphy and CSM.

and conventional staging procedures resulted in a change of Ann Arbor clinical stage. SS-R scintigraphy findings correctly upgraded the clinical stage in 11 cases and the clinical stage was correctly downgraded in one patient. As a result the treatment plan was altered in seven patients. In all seven patients the superiority of SS-R scintigraphy was supported by additional evidence.

False-negative results of SS-R scintigraphy (four patients)

In four patients SS-R scintigraphy did not show localizations which had become apparent following radiological methods (see Table III). In patients 3, 7 and 26 enlarged abdominal para-aortic lymph nodes visualized on CT and lymphangiography were not apparent on SS-R scintigraphy images. The largest non-visualized lesion in the abdominal area had a diameter of $4.5 \mathrm{~cm}$. In all three patients the enlarged para-aortic lymph nodes disappeared after treatment. In the fourth patient (40), SS-R scintigraphy demonstrated a normal-sized spleen with a homogenous distribution of radioactivity, but CT and sonography showed a spleen of normal size with multiple hypodense areas, which disappeared following chemotherapy. In these four patients in whom SS-R scintigraphy missed certain localizations of HD,
Table VI. Concordance between SS-R scintigraphy and conventional staging methods in 28/56 patients with HD.

\begin{tabular}{lll}
\hline $\begin{array}{l}\text { No. of } \\
\text { patients }\end{array}$ & Sites of disease & $\begin{array}{l}\text { Clinical } \\
\text { stage }\end{array}$ \\
\hline 13 & Neck, mediastinum & II \\
4 & Neck & I \\
4 & Neck, axilla, mediastinum & II \\
2 & Mediastinum & I \\
1 & Neck, bone marrow* & IV \\
1 & Neck, axilla, mediastinum, & III \\
& $\begin{array}{l}\text { para-aortic } \\
\text { Neck, mediastinum, }\end{array}$ & III \\
1 & $\begin{array}{l}\text { para-aortic, spleen } \\
\text { Neck, mediastinum, lung }\end{array}$ & IV \\
1 & Neck, axilla, inguinal, & IV \\
& mediastinum, para-aortic, & \\
& spleen, lung & \\
\hline
\end{tabular}

\footnotetext{
*Bone marrow involvement not apparent on SS-R scintigraphy.
}

the clinical stage, if based on SS-R scintigraphy only, would have been underestimated in one individual.

Spleen and abdominal lymph node involvement with HD What about the performance of SS-R scintigraphy with regards to abdominal involvement with HD? The spleen was enlarged in seven patientsaccording to CT and sonography. In five of these individuals multiple hypodense areas were also apparent (see Table IV). In all seven patients SS-R scintigraphy showed an enlarged spleen with a homogenous distribution of radioactivity. In an eighth patient (no. 40), where CT and sonography showed multiple hypodense areas in a normal-sized spleen, the spleen appeared normal on SS-R scintigraphy. Therefore SS-R scintigraphy failed to demonstrate spleen involvement in one patient. Enlarged abdominal para-aortic lymph nodes were seen on CT and lymphangiography in eight patients, five of whom were also SS-R

Table V. False-positive SS-R scintigraphy in 3/56 patients with HD: a comparison between SS-R scintigraphy and conventional staging methods.

\begin{tabular}{lllll}
\hline Pt & $\begin{array}{l}\text { Sites of disease: } \\
\text { conventional methods }\end{array}$ & $\begin{array}{l}\text { Clinical stage: } \\
\text { conventional } \\
\text { methods }\end{array}$ & $\begin{array}{l}\text { Sites of disease: } \\
\text { SS-R scintigraphy }\end{array}$ & $\begin{array}{l}\text { Reason false-positive } \\
\text { SS-R scintigraphy }\end{array}$ \\
\hline 42 & $\begin{array}{l}\text { Right neck, left/right axilla, } \\
\text { mediastinum }\end{array}$ & II & $\begin{array}{l}\text { Right neck, left/right axilla, } \\
\text { mediastinum, nasal region } \\
\text { Left neck, mediastinum, } \\
\text { anterior iliac spine } \\
\text { Left/right neck, mediastinum } \\
\text { nasal region }\end{array}$ & Haematoma \\
49 & Left neck, mediastinum & II & II & Common cold \\
\hline
\end{tabular}


scintigraphy positive (see Table IV). The smallest lymphoma within the abdomen demonstrated by SS-R scintigraphy had a diameter of approximately $2.0 \mathrm{~cm}$. In five other patients para-aortic lymph nodes were visualized on SS-R scintigraphy that had not been detected on CT and lymphangiography. In three of these five patients the para-aortic SS-R-positive lesions disappeared after chemotherapy. In the other two patients SS-R scintigraphy was not repeated. One patient had enlarged parailiac lymph nodes on CT and these were also visualized by SS-R scintigraphy.

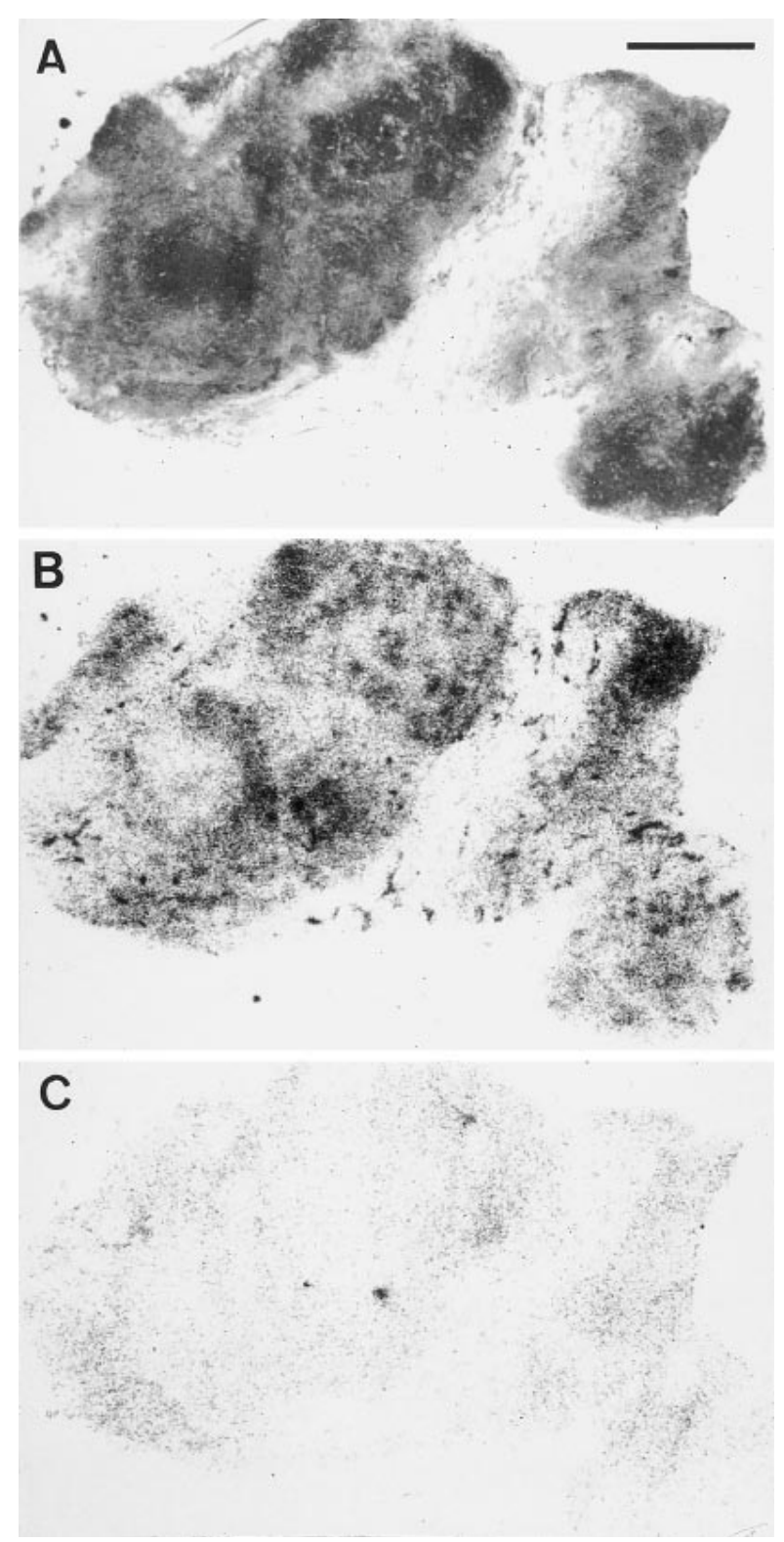

Fig 3. Somatostatin receptors in a case of Hodgkin's lymphoma (A) Haematoxylin-eosin-stained section. Bar $=1 \mathrm{~mm}$. (B) Autoradiogram showing total binding of ${ }^{125} \mathrm{I}-\left[\mathrm{Tyr}^{3}\right.$ ]octreotide (C) Autoradiogram showing nonspecific binding of ${ }^{125} \mathrm{I}-\left[\mathrm{Tyr}^{3}\right]$ octreotide (in presence of $10^{-6} \mathrm{M}$ of unlabelled [Tyr ${ }^{3}$ ]octreotide).
False-positive results of SS-R scintigraphy (three patients) In three patients the positivity on SS-R scintigraphy on selected sites clearly was not related to localizations of HD (see Table V). In two patients accumulation of radioactivity was observed in the nasal region. A sinusitis in one patient and a common cold in the other patient had caused the positive scan. The third patient showed abnormal accumulation of radioactivity in the anterior iliac spine after a bone marrow biopsy at that site.

F urther results of SS-R scintigraphy and SS-R autoradiography In 28/55 SS-R-positive patients the results of SS-R scintigraphy and conventional staging methods were concordant. Thesites of diseaseand clinical stagesare summarized in Table VI. The smallest lymph node identified by SS-R scintigraphy located in the neck had a diameter of $1.0 \mathrm{~cm}$. The only patient with an entirely negative SS-R scintigraphy had stage IVB HD with lymph nodes in the axilla and an infiltrated bone marrow.

Finally, side-effects were not noted in any of the patients following the administration of $\left[{ }^{111}\right.$ In-DTPA-D-Phe ${ }^{1}$ octreotide for SS-R scintigraphy.

In three patients SS-R analysis was performed on surgically removed lymph nodes. Autoradiographic investigation confirmed the presence of specific SS-Rs in the tissue biopsies of malignant lymphoma in these individuals (Figs $3 \mathrm{~A}-\mathrm{C}$ ). These lymph nodes were all positive in vivo on SS-R scintigraphy.

\section{DISCUSSION}

The accuracy of staging is a cornerstone of the treatment of patients with HD. Clearly, current staging is still highly inadequate. For instance, stage I and II patients considered at high risk of failure are frequently treated with systemic chemotherapy. For this purpose, in stages I and II, clinical prognostic factors are employed to select between locoregional or systemic therapy. Following treatment it may be difficult to distinguish between persisting active HD or fibrotic abnormalities, e.g. in case of residual radiological mediastinal masses still apparent following chemotherapy.

In the present study we employed SS-R scintigraphy in 56 consecutive patients with histologically proven HD. A mong these, $98 \%$ of the patients showed a positive SS-R scan. SS-Rpositive localizations were apparent at different sites of active disease above and bel ow the diaphragm. Since the pathophysiological basis of SS-R scintigraphy staging bears no relationship to that of the other diagnostic imaging techniques, SS-R scintigraphy appears to provide an independent approach to the evaluation of the dissemination of HD. ThereforeSS-R scintigraphy may add essential information to the results of the complete staging process. The discrepancies between the results of SS-R scintigraphy and conventional staging work-up as reported here support this. In only 28 patients was complete concordance apparent between SS-R scintigraphy and physical examination, $\mathrm{X}$-ray examination, CT scanning and lymphangiography.

Autoradiography demonstrated the presence of SS-Rs in the lymphoma tissues surgically removed from three patients with HD. $\quad{ }^{111} \mid$ n-DTPA-D-Phe ${ }^{1}$ octreotide and $\left[{ }^{125} \mid-\right.$ Tyr $\left.^{3}\right]$ - 


\section{P. J. van den Anker-Lugtenburg et al}

octreotide bind with high affinity and specificity to the same receptor (Bakker et al, 1991). The identification of SS-Rs in vitro in biopsies from the lymph nodes with HD, confirms that the activity seen in vivo actually represented SS-Rpositive tumour tissue. In patients with histologically proven HD the tumours display SS-Rs of high enough affinity and density to apparently permit external imaging by the radiolabelled SS analogue in most cases.

In 20 patients SS-R scintigraphy disclosed lesions not revealed following a variety of radiodiagnostic procedures. In most of these individuals additional investigations were undertaken in an effort to verify the diagnosis of HD at sites of discrepancy.

SS-R scintigraphy failed to demonstrate certain sites of HD in four cases and SS-R scintigraphy was entirely negative in one individual with extensive involvement of $\mathrm{HD}$. In a significant proportion of cases the clinical stage as defined by conventional staging methods changed following consideration of the results of SS-R scintigraphy. In 11 cases of the entire series of 56 subjects the disease was upgraded to a higher stage. The additional information of SS-R scintigraphy resulted in a different choice of therapy in seven patients (13\%).

As compared with conventional staging methods, SS-R imaging offers a number of distinct advantages. First, because the whole body is imaged, localizations in areas not under clinical suspicion can be evaluated, and therefore the full extent of the disease more accurately documented. Second, after treatment with chemo- or radiotherapy, residual or recurrent tumours of malignant lymphomas remain SS-R positive (Reubi et al, 1992). SS-R scintigraphy may be potentially useful to assess remission and avoid 'over treatment' in patients in remission. SS-R scintigraphy may also be of use in the management of residual masses, including the notoriously difficult mediastinal localizations. Our preliminary experience in two patients with primary resistant HD gives some support that this may be true (data not shown). After six cycles of chemotherapy a residual mass was seen on CT in the mediastinum in one patient and in the para-aortic region of the abdomen in the second. SS- $R$ scintigraphy was positive in these areas in both patients. Histologic confirmation of active HD at the latter sites was obtained in both patients. We are presently investigating the role of SS-R scintigraphy in the evaluation of treatment response in patients with $\mathrm{HD}$ in a prospective study.

In the abdominal region SS-R scintigraphy (unlike conventional techniques) revealed para-aortic lymph nodes in five patients. A repeated SS-R scintigraphy after chemotherapy in three of these patients showed total disappearance of the lesions. In 12 cases there was complete agreement between the results of SS-R scintigraphy and conventional radiodiagnostictechniquesin the detection of abdominal sites of HD. SS-R scintigraphy failed to detect abdominal HD in four patients. Para-aortic lymph nodes were missed in three patients and spleen involvement was not apparent on SS-R scintigraphy in one patient. Thus, all false-negative cases of our series were located in the abdomen. This problem was also seen in patients with carcinoid tumours where planar images of SS-R scintigraphy failed to detect some liver metastases (Kwekkeboom et al, 1993). The visualization of abdominal lymphoma localizations with $\left[{ }^{111}\right.$ In-DTPA-D$\mathrm{Phe}^{1}$ ]octreotide may be limited by a number of factors. The human spleen expresses high-affinity SS-Rs (Reubi et al, 1993). Frequently lymphoma metastases in the spleen appear to accumulate a similar amount of radioactivity as does surrounding normal spleen tissue. After intravenous injection, $\left[{ }^{111} \mathrm{In}\right.$-DTPA-D-Phe $\mathrm{e}^{1}$ octreotide is rapidly cleared from the blood, predominantly excreted via the kidneys, and a minority of the isotope removed by hepatobiliary clearance (Krenning et al, 1992). The hepatobiliary clearance results in hepatic and intestinal accumulation of radioactivity. The presence of intestinal radioactivity can usually be overcome by the use of laxatives. Nevertheless, in some patients radioactivity may remain in the colon and this may interfere with the detection of para-aortic lymph nodes. The physiological uptake of radioactivity in the liver, although less than in the spleen, may reduce optimal detection of liver involvement with SS-R-positive tumours. Overprojection of radioactivity of the liver, spleen and kidneys can hide positive lesions in lymph nodes on the planar images. The use of SPECT images of the upper abdomen in part may overcome this problem and is therefore recommended for the localization of abnormal lymph nodes in the spleen and liver hilar areas. The same is true for the para-aortic region of the upper abdomen.

SS-R scintigraphy is not specific for visualizing tissue involved with HD. Granulomatous diseases, autoimmune diseases and neuroendocrine tumours may result in positive SS-R scintigraphy images as well (Krenning et al, 1993; Vanhagen et al, 1994). Obviously, therefore, SS-R scintigraphy cannot be used to diagnose malignant lymphoma. In this respect, SS-R scintigraphy shares the general limitations of most imaging techniques. In our study, three false-positive results were seen. In two cases the positivity in the nasal region on the scan was caused by an infection; clinically, these two patients had a common cold. This transient accumulation in the nasal region during the typical season of epidemic common cold/influenza is a well-known pitfall in the correct interpretation of SS-R scintigraphy (Krenning et al, 1993). The third patient showed accumulation of radioactivity in the pelvis after bonemarrow biopsy. Clinically a large haematoma was apparent. Our accumulated experience in more than a thousand patients has taught us that radioactivity may accumulate at sites of recent operation.

In several centres gallium scintigraphy is used in the workup of HD patients. Gallium scintigraphy is performed prior to therapy to provide information on the gallium avidity of the tumour at baseline. Current evidence would indicate that the sensitivity of gallium scintigraphy in the initial staging of patients with HD is in the order of 66-85\% (Front et al, 1990; Hagemeister et al, 1990). The most important value of gallium scintigraphy is therefore not in the initial staging of patients with HD but rather in the evaluation of lymphoma after treatment (Front et al, 1995). It would be of interest to compare SS-R scintigraphy and gallium scintigraphy in the staging of HD in future studies. In this age of financial restraint these imaging techniques should be cost-effective. In Rotterdam a prospective cost-effective study is currently in 
progress that includes ultrasonography, computed tomography, galliumscintigraphy and SS-R scintigraphy.

In conclusion, SS-R scintigraphy provides a useful method of diagnostic evaluation of patients with HD. It is a relatively easy and harmless procedure. Obviously, further prospective studies in larger groups of patients, both pre- and posttreatment, will be needed to fully define its value and place in the management of patients with HD.

\section{REFERENCES}

Bakker, W.H., Albert, R., Bruns, C., Breeman, W.A.P., Hofland. L.J., Marbach, P., Pless, J., Koper, J.W., Lamberts, S.W.J., Visser, T.J. \& Krenning, E.P. (1991) ${ }^{111}$ In-[DTPA-D-Phe ${ }^{1}$-octreotide, a potential radiopharmaceutical for imaging of somatostatin receptor positive tumors: radiolabeling and in vitro validation. Life Sciences, 49, 1583-1591.

Bares, R., Galonska, P., Dempke, W., Handt, S., Bull, U. \& Osieka, R. (1993) Somatostatin receptor scintigraphy in malignant lymphoma: first results and comparison with glucose metabolism measured by positron-emission tomography. Hormoneand M etabolic Research Supplement, 27, 56-58.

Bong, S.B., VanderLaan, J.G., Louwes, H. \& Schuurman, J.J. (1994) Clinical experience with somatostatin receptor imaging in lymphoma. Seminars in Oncology Supplement, 21, 46-50.

Carbone, P.P., Kaplan, H.S., Musshoff, K., Smithers, D.W. \& Tubiana, M. (1971) Report of the committee on Hodgkin's disease staging classification. Cancer Research, 31, 1860-1861.

Front, D. \& Israel, O. (1995) The role of Ga-67 scintigraphy in evaluating the results of therapy in lymphoma patients. Seminars in Nudear M edicine, 25, 60-71.

Front, D., Israel, O., Epelbaum, R., Ben Haim, S., Even Sapir, E., Jerushalmi, J., Kolodny, G.M. \& Robinson, E. (1990) Ga-67 SPECT before and after treatment of lymphoma. Radiology, 175, 515-519.

Hagemeister, F.B., Fesus, S.M., Lamki, L.M. \& Haynie, T.P. (1990) Role of the gallium scan in Hodgkin's disease Cancer, 65, 1090-1096.

Krenning, E.P., Bakker, W.H., Breeman, W.A.P., Koper, J.W., Kooij, P.P.M., Ausema, L., Lameris, J.S., Reubi, J.C. \& Lamberts, S.W.J. (1989) Localization of endocrinerelated tumours with radioiodinated analogue of somatostatin. Lancet, i, 242-244.

Krenning, E.P., Bakker, W.H., Kooij, P.P.M., Breeman, W.A.P., Yoe Oei, H., de Jong, M., Reubi, J.C., Visser, T.J., Bruns, C., Kwekkeboom, D.J., Reijs, A.E.M., van Hagen, P.M., Koper, J.W. \& Lamberts, S.W.J. (1992) Somatostatin receptor scintigraphy with Indium-111DTPA-D-Phe-1-octreotide in man: metabolism, dosimetry and comparison with Iodine-123-Tyr-3-octreotide Journal of Nudear M edicine, 33, 652-658.

Krenning, E.P., Kwekkeboom, D.J., Bakker, W.H., Breeman, W.A.P., Kooij, P.P.M., Yoe Oei, H., van Hagen, M., Postema, P.T.E., de Jong, M., Reubi, J.C., Visser, T.J., Reijs, A.E.M., Hofland, L.J., Koper, J.W. \& Lamberts, S.W.J. (1993) Somatostatin receptor scintigraphy with $\left[{ }^{111} \mathrm{In}\right.$-DTPA-D-Phe $\left.{ }^{1}\right]$ and $\left[{ }^{123} \mid-\mathrm{Tyr}^{3}\right]$-octreotide: the Rotterdam experience with more than 1000 patients. European Journal of Nudear M edicine, 20, 716-731.

Krenning, E.P., Kwekkeboom, D.J., de Jong, M., Visser, T.J., Reubi, J.C., Bakker, W.H., Kooij, P.P.M \& Lamberts, S.W.J. (1994) Essentials of peptide receptor scintigraphy with emphasis on the somatostatin analog octreotide. Seminars in Oncology, 21, 6-14.

Krenning, E.P., Kwekkeboom, D.J., Lamberts, S.W.J., Pauwels, S., Kvols, L. \& Reubi, J.C. (1995) Somatostatin receptor scintigraphy.
Nuclear M edicine Annual (ed. by L. M. Freeman), pp. 1-50. Raven Press, New York.

Kwekkeboom, D.J., Krenning, E.P., Bakker, W.H., Yoe Oei, H., Kooij, P.P.M. \& Lamberts, S.W.J. (1993) Somatostatin analogue scintigraphy in carcinoid tumours. European Journal of Nudear M edicine, 20, 283-292.

Lamberts, S.W.J., Bakker, W.H., Reubi, J.C. \& Krenning, E.P. (1990) Somatostatin-receptor imaging in the localization of endocrine tumors. New England Journal of M edicine, 323, 1246-1249.

Lipp, R.W., Silly, H., Ranner, G., Dobnig, H., Passath, A., Leb, G. \& Krejs, G.J. (1995) Radiolabeled octreotide for the demonstration of somatostatin receptors in malignant lymphoma and lymphadenopathy. Journal of Nudear M edicine, 36, 13-18.

North, L.B. \& Jing, B.S. (1988) Imaging procedures. Hodgkin's Disease and Non-Hodgkin's Lymphomas in Adults and Children (ed. by L. Fuller), pp. 130-169. Raven Press, New York.

Reubi, J.C., Heitz, P.U. \& Landolt, A.M. (1987) Visualization of somatostatin receptors and correlation with immunoreactive $\mathrm{GH}$ and PRL in human pituitary adenomas: evidence for different tumor subclasses. Journal of Clinical Endocrinology and M etabolism, 65, 65-73.

Reubi, J.C., Kvols, L.K., Waser, B., Nagorney, D.M., Heitz, P.U., Charboneau, J.W., Reading, C.C. \& Moertel, C. (1990a) Detection of somatostatin receptors in surgical and percutaneous needle biopsy samples of carcinoids and islet cell carcinomas. Cancer Research, 50, 5959-5977.

Reubi, J.C., Maurer, R., Klijn, J.G.M., Stefanko, S.Z., Foekens, J.A., Blaauw, G., Blankenstein, M.A. \& Lamberts, S.W.J. (1986) High incidence of somatostatin receptors in human meningiomas: biochemical characterization. Journal of Clinical Endocrinology and M etabolism, 63, 433-438.

Reubi, J.C., Waser, B., Foekens, J.A., Klijn, J.G.M, Lamberts, S.W.J. \& Laissue, J. (1990b) Somatostatin receptor incidence and distribution in breast cancer using receptor autoradiography: relationship to EGF-receptors. International Journal of Cancer, 46, 416-420.

Reubi, J.C., Waser, B., Horisberger, U., Krenning, E., Lamberts, S.W.J., Gebbers, J.O., Gersbach, P. \& Laissue, J.A. (1993) In vitro autoradiographic and in vivo scintigraphic localization of somatostatin receptors in human lymphatic tissue. Blood, 82, 21432151.

Reubi, J.C., Waser, B., Sheppard, M. \& Macaulay, V. (1990c) Somatostatin receptors are present in small-cell but not in nonsmall-cell primary lung carcinomas: relationship to EGF-receptors. International Journal of Cancer, 45, 269-274.

Reubi, J.C., Waser, B., van Hagen, M., Lamberts, S.W.J., Krenning, E.P., Gebbers, J.O. \& Laissue, J.A. (1992) In vitro and in vivo detection of somatostatin receptors in human malignant lymphomas. International Journal of Cancer, 50, 895-900.

van Eijck, C.H.J., Krenning, E.P., Bootsma, A., Yoe Oei, H., van Pel, R., Lindemans, J., Jeekel, J., Reubi, J.C. \& Lamberts, S.W.J. (1994) Somatostatin receptor scintigraphy in primary breast cancer. Lancet, 343, 640-643.

van Hagen, P.M., Krenning, E.P., Reubi, J.C., Mulder, A.H., Bakker, W.H., Yoe Oei, H., Löwenberg, B. \& Lamberts, S.W.J. (1993) Somatostatin analogue scintigraphy of malignant lymphomas. British Journal of Haematology, 83, 75-79.

Vanhagen, P.M., Krenning, E.P., Reubi, J.C., Kwekkeboom, D.J., Bakker, W.H., Mulder, A,H., Laissue, I., Hoogstede, H.C. \& Lamberts, S.W.J. (1994) Somatostatin analogue scintigraphy in granulomatous diseases. European Journal of Nudear M edicine, 21, 497-502. 